\title{
A brief history of the cryptogams of Fiji and prospects for the future
}

\author{
Matt von Konrat ${ }^{1}$, Alifereti Naikatini ${ }^{2}$, Marika Tuiwawa², \\ Lars Söderström ${ }^{3}$, Allan Fife ${ }^{4}$, Matt Renner ${ }^{5}$, Patrick Brownsey ${ }^{6}$, \\ Leon Perrie ${ }^{6}$, Anders Hagborg ${ }^{1}$, Tamás Pócs ${ }^{7}$, \\ H. Thorsten Lumbsch', John Braggins ${ }^{8}$ Ana Séneca ${ }^{3,9}$, and \\ Elizabeth Brown ${ }^{5}$
}

\author{
${ }^{1}$ Botany Department, The Field Museum, Chicago, Illinois 60605-2496, U.S.A. \\ ${ }^{2}$ South Pacific Regional Herbarium, Institute of Applied Science, Faculty of Science and \\ Technology, University of the South Pacific, Private Bag, Laucala Campus, Suva, Fiji \\ ${ }^{3}$ Department of Biology, Norwegian University of Science and Technology, \\ N-7491 Trondheim, Norway \\ ${ }^{4}$ Landcare Research, PO Box 40, Lincoln 7640, New Zealand \\ ${ }^{5}$ National Herbarium of New South Wales, Royal Botanic Gardens Sydney, NSW, Australia \\ ${ }^{6}$ Museum of New Zealand Te Papa Tongarewa, P.O. Box 467, Wellington, New Zealand \\ ${ }^{7}$ Botany Department, Eszterházy College, Eger. Pf. 43, H-3301, Hungary \\ ${ }^{8}$ Herbarium, The Auckland War Memorial Museum, Private Bag 92018, Auckland 1142, \\ New Zealand \\ ${ }^{9}$ Department of Biology, Faculty of Science, University of Porto, Rua Campo Alegre, \\ s/n, P-4169-007 Porto, Portugal
}

\begin{abstract}
A brief history of Fijian cryptogams, including bryophytes, ferns and lycophytes, and lichenised fungi, is provided. Brief comments on the future prospects for the systematics and conservation of these groups of organisms are provided. An overview of the six Fijian contributions is also provided. In contrast to many other biodiversity hotspots, the current study highlights our limited floristic knowledge of the Fijian cryptogams.
\end{abstract}

\section{Introduction}

The current issue of Telopea (volume 13, part 3) is dedicated to bryophytes, ferns and lycophytes, as well as lichenised fungi from the islands of Fiji. These organisms all share the common feature of being spore-bearing and traditionally their members have been classified together and referred to as cryptogams. Although cryptogams do not form a natural monophyletic group, they do share many ecological and physiological traits, and are typically found together in moist habitats. For example, lichens and bryophytes are relatively small organisms (when compared with most land plants) that 
often produce species-diverse mats over rock, soil, and tree bark; they are poikilohydric and can survive periods of drought in non-metabolic stages (Bates \& Farmer 2002, Cornelissen et al. 2007). Bryophytes, ferns and lycophytes as well as lichenised fungi are of ecological significance in a variety of ecosystems, and participate in key ecological functions such as erosion prevention, plant succession, production of phytomass, decomposition, and are primary producers in the cycling of carbon and nitrogen (Page 1979; Pócs 1980; Longton 1984, 1992; Coxson et al. 1992). Many of these organisms contain compounds with useful biochemical properties such as anti-microbial, antifungal, cytotoxic, insect anti-feedant, and muscle relaxing activity (Soeder 1985; Asakawa 1995, 2004). As a source of food and building material, ferns are an important component of Fijian culture. Some notable examples include the use of Cyathea in the construction of huts (Bure), and the consumption of palatable ferns (Ota) such as Acrostichum aureum, Coniogramme fraxinea, Diplazium spp. and Tectaria degeneri (Parham 1972).

Lichens are classified as fungi (predominately ascomycetes, Nash 2008) whereas bryophytes are related to vascular plants, including ferns and lycophytes (Kenrick \& Crane 1997). Neither lichens nor bryophytes are monophyletic. Lichens are a polyphyletic assembly of heterogeneous clades (e.g. Lutzoni et al. 2001, Miadlikowska et al. 2006, Schoch et al. 2009). For bryophytes, there is a broad consensus that its members are a paraphyletic grade of several distinct lineages; i.e. Marchantiophyta (liverworts), Anthocerotophyta (hornworts), and Bryophyta (mosses) (e.g. Mishler \& Churchill 1984, Kenrick \& Crane 1997, Shaw \& Renzaglia 2004, Qiu et al. 2007). Similarly, those plants historically classified as 'pteridophytes' and 'ferns and fern allies'represent a paraphyletic assemblage, including the lycophytes, horsetails, whisk ferns, and all eusporangiate and leptosporangiate ferns (Smith et al. 2006).

Mittermeier et al. (2005) identified all the islands of Micronesia and Polynesia, including the islands of Fiji, as one of 35 global biodiversity 'hotspots', often referred to as the Polynesia-Micronesia hotspot. Conservation International (http://www.wdpa. org, accessed 16 Aug 2011) considers the Polynesia-Micronesia hotspot the epicenter of the current global extinction crisis. Geographically, the islands belong to Melanesia, a subregion of Oceania, which includes New Guinea, the Solomon Islands, Vanuatu, New Caledonia and Fiji but phytogeographically some regard the Fiji group as belonging to Eastern Melanesia with an obvious transition towards Polynesia(Mueller-Dombois \& Fosberg 1998). The Fiji Islands comprise a mountainous archipelago of over 300 islands of varying sizes, in the tropical south-west Pacific with a land area of 18376 $\mathrm{km}^{2}$, approximately half of which is covered in rain forest (DoE 1997, Heads 2006). The tropical moist forests of Fiji contain the richest and most distinct natural communities of all the oceanic islands of the Pacific, with the exception of New Caledonia (World Wildlife Fund), and more than $60 \%$ of the Fijian seed plant flora is considered endemic (Watkins 1994, Heads 2006). Fiji has a complex geology, which is determined by its position between two subduction-zones of opposite polarity, the Vanuatu and Tonga Trenches, in what is currently a region of transform faulting (Heads 2006).

The distribution of many Fijian species can be localised to single islands or mountains, this being a factor regarding vulnerability to human disturbance (Davis et al. 1995). Loss and/or degradation of characteristic ecosystems such as mangroves and lowland rainforest is a consequence of years of logging and land clearing to make way for plantation forests, other agricultural practices, and human habitation (Watling \& Chape 1992). Keppel (2005) suggested that there is much to learn regarding the 
composition and distribution of plant communities in many areas of Fiji, the urgency of which is compounded when one considers only $1.4 \%$ of Fiji is under some form of environmental protection (World Database on Protected Areas, http://www.wdpa. org, accessed 16 Aug 2011). However, the situation is even worse for bryophytes and lichenised fungi. The lack of comprehensive baseline data is exemplified by the total absence of data for bryophytes and lichens in the National Report prepared by the Fijian Department of the Environment (DoE 1997), along with subsequent reports as part of the Convention on Biological Diversity, despite data being produced for vascular plants, invertebrates, birds, and animals.

\section{Brief history of cryptogam exploration}

The Fijian islands were not visited by the British and French expeditions of the 18th and early 19th centuries (Brownlie 1977). The earliest major western botanical exploration was by the United States Exploring Expedition in 1840 (Brownlie 1977), which was largely prompted by a desire to obtain information on the South Pacific, an area that was rapidly becoming of interest to American traders and whalers (Engel \& Glenny 2008). As noted by Brownlie (1977), none of the explorers in the 18th century, and very few in the early 19th century limited themselves to the study of particular plant groups; thus ferns along with other cryptogams were included due only to the non-specific nature of the botanical collecting. One of the earliest and most significant floristic works devoted to Fiji was Flora Vitiensis which was published in ten parts (with colour plates by Walter H. Fitch) and included many new plant genera and species (Seemann 1865-1873). German botanist Berthold Carl Seemann produced the first issue in 1865; nine parts were written by him, but unfortunately Seemann died before the completion of the tenth part, in which he intended to deal with the cryptogamic plants. The final part was instead authored by W. Carruthers (ferns), J. M. Crombie (lichens) and W. Mitten (bryophytes) and issued in 1873 (Stearn 1963).

Bryophytes - Very few publications have focused solely on bryophyte collections from Fiji, especially when compared to all other land plant groups. Moreover, there have been very few bryophyte collections made in Fiji since the end of the Second World War (after 1945).

Based on 1840 collections made by W.D. Brackenridge, the botanist of the United States Exploring (Capt. C. Wilkes) Expedition, Schultze-Motel (1974) noted that the earliest published records of Fijian mosses are apparently those of Sullivant $(1854,1859)$. Other early collections were made by W. Milne (of the Herald expedition under Capt. Denham) in 1856 and by Seemann and Graeffe (c. 1860). All these were incorporated into Mitten's (1873a) treatment of the mosses in Seemann's Flora Vitiensis. In the 20th century, Lillian Gibbs (as quoted by Dixon \& Greenwood, 1930) reported on montane mosses collected in 1907 from near Tomanivi (Mt Victoria), Viti Levu. From 1917 onwards significant collections from Viti Levu, Vanua Levu, and Ovalau Islands were made by William Greenwood. Greenwood's collections, together with those of a number of less prolific collectors, were summarised in the still useful paper by Dixon \& Greenwood (1930) and, after Dixon's death, Greenwood (1945) presented a subsequent paper. Collections by A.C. Smith, made mostly from out-lying islands between 1933 and 1948, O. Degener's collections of 1940-41, and some residual Greenwood collections formed the basis of a series of papers by the American bryologist E.B. Bartram spanning more than two decades (e.g. Bartram 1936, 1948, 1956). These publications form the 
core of our current knowledge of the islands' moss flora. They were incorporated into both Katalog der Laubmoose von Melanesien (Schultze-Motel 1974) and A preliminary list of Fijian mosses (Whittier 1975). Whittier's list, compiled from literature reports, recorded 306 species and varieties in 106 genera from Fiji. Prodromus Florae Muscorum Polynesiae (Miller et al. 1978) also incorporated literature records from Fijian islands. It also included an extremely useful key to the genera recorded from its wide area of coverage. Eddy's $(1988,1990,1996)$ uncompleted series, A Handbook of Malesian Mosses, flora is another valuable resource for the study of Fijian mosses.

Subsequent Fijian collections seem to have been primarily by M. Higuchi and Z. Iwatsuki in 1982 and 1991-92 (see Matsui \& Iwatsuki, 1993) and S. \& T. Pócs in 2003. A few of Pócs' collections are cited in Pócs et al. (2011, this issue) but many of them remain unstudied. Valuable collections made during trips (Fig. 1, Table 1) by authors of the current paper, i.e. E. Brown, M. Renner, M. von Konrat, J. Braggins, A. Fife and others have also yet to be critically revised, but initial processing indicates many novelties. The Fijian moss flora remains extremely poorly collected and a very large fraction of the species recorded in the past have not yet been critically evaluated. Bartram's (1936) opinion that "further explorations, especially in the higher regions of central Viti Levu" would expand this number considerably remains true today. This is evident with Fife \& Naikatini (2011, this issue) recording nine new distributional records for Fiji.

Many of the earliest publications of Fijian liverworts and hornworts were based on collections made by Brackenridge, Milne and Graeffe. Mitten $(1861,1862)$ described a few new species from Fiji, and afterwards provided a more detailed treatment as part of Flora Vitiensis (Mitten 1873b). Later, Jack and Stephani (1894) described several new species based on collections made by Graeffe. Gibbs (1909) reported on 21 liverworts and 2 hornworts from Viti Levu, thus adding many new records to Fiji.

The last significant report on Fijian liverworts and hornworts was produced by Campbell (1971), and was based on collections made by A.C. Smith and W. Greenwood. At that time, Campbell stated that there were still few collections from Fiji, and hoped her work would provide an impetus for further studies. Miller et al. (1983) published a comprehensive checklist of liverworts and hornworts from the tropical islands of the Pacific, including those of Fiji. This work was based on a compilation of literature and served as a first step towards making knowledge about Pacific island bryophytes more accessible. Miller et al. (1983) concluded that the bryophyte flora of the tropical Pacific islands was poorly known and much work remained to be done to produce a useful Flora for the region. There does exist a scattering of publications that have included collections from Fiji as part of other broader geographical, monographic and revisional studies (e.g. the series of papers published by H. Hürlimann on the Hepaticae of Southern Pacific in 14 parts between 1960 and 1998; Eddy 1988, 1990, 1996; Hattori 1985; Iwatsuki \& Suzuki 1996; Matsui \& Iwatsuki 1993; Schuster \& Engel 1985; Thiers 1993; So 2002; von Konrat et al. 2006), but these only cover a fraction of the flora represented in the region.

Ferns and lycophytes - Early works included those of W. Carruthers who provided a synopsis of the ferns, in Seemann's Flora Vitiensis, and Brackenridge (1854) who provided an enumeration and description of all the ferns collected during the voyage of the United States Exploring Expedition between 1838 and 1842. Brownlie (1977) noted that Brackenridge reported almost half of the now known flora, which was remarkable considering the difficulties of inland travel at that time. Brownlie (1977) 
provided a detailed discussion of the different periods of botanical expeditions, major publications of pteridophytes relating to Fiji and a comprehensive treatment of the group. He treated substantially, c. 30\%, more taxa than Copeland (1929) had dealt with (Godley 2000). Since publication of Brownlie's work, 29 species have been added to the Fijian fern flora (Brownsey \& Perrie 2011, this issue). During the last 25 years, as in bryology and lichenology, there have been few publications devoted to ferns of Fiji, and many have been part of larger treatments. Some noteworthy publications during that time include Parris (1994), Kramer \& Zogg (1988), Kato (1984), Gardner (1997) and Brownsey (1987).

Lichenised fungi - Crombie noted that it was regrettable that the few botanical collectors who had visited Fiji, as in many other regions at the time, "paid so little attention to this interesting class of cryptogams" and that a "rich harvest awaits the researchers of future collectors" (Seemann 1865-1873). Indeed, over 140 years later the lichen flora of Fiji remains extremely poorly known (Lumbsch et al. 2011b, this issue). Very early works on lichens in Fiji include Crombie's enumeration of seven lichen species as part of Seemann's Flora Vitiensis (1865-1873), and Krempelhuber (1868) who listed several species in a paper on lichens from the South Pacific with a later record of additional species from Fiji (Krempelhuber 1873). Over recent years, only a few studies have focused specifically on Fijian lichens (Archer 2004, Elix 2001, Lücking et al. 2010, Lumbsch et al. 2009, McCarthy \& Elix 2000, Molho et al. 1981). A recently updated checklist of Fijian lichens includes data on 159 species (Elix \& McCarthy 1998, 2008).

\section{Enduring impediments}

For many groups of organisms there exists a large amount of nomenclatural and distributional data dispersed throughout the literature, as well as undatabased and undocumented information. Together with the lack of critical evaluation of specimens, this presents a major impediment for the documentation and analysis of species richness and distribution patterns, and conservation research at both regional and global scales (von Konrat et al. 2008). However, for some organisms, there has been a strong effort toward synthesizing this information, e.g. http://www.mycology.net an internet portal for scientists presenting information about the diversity of fungi, and the Early Land Plants Today (ELPT) project - an international consortium of scientists working towards uniting biological data for liverworts and hornworts (von Konrat et al. 2010).

Two kinds of error are often associated with early exploration of the Pacific (and other tropical areas). These have, on occasion, been propagated in the literature by subsequent regional treatments. First, many taxa were identified uncritically as European taxa under various names that are still the basis for many reports, although some have subsequently been rejected. For example, Riccardia chamedryfolia is a boreal taxon reported from many areas of the tropics including the Pacific. It was reported from Fiji by Schiffner (1890; as Aneura pinnatifida) but that is now rejected (Söderström et al. 2011, this issue). However, for several other taxa, we do not know what they really represent, since we lack recent studies for the area (e.g. Aneura pinguis; Söderström et al. 2011, this issue). Secondly, participants on several early expeditions were not very exact in labelling their collections and many specimens now bear erroneous locality details. For example, William Milne who was the botanist collecting on the HMS 
Table 1. Brief description of general area and elevation providing an impression of major collecting sites discussed in Fife \& Naikatini (2011), Lumbsch et al. (2011b) and Pócs et al. (2011), (all this issue). Precise locality details are provided in the above papers.

$\begin{array}{llll}\begin{array}{l}\text { Site } \\ \text { no. }\end{array} & \begin{array}{l}\text { See authors } \\ \text { (this issue) }\end{array} & \text { Island } & \begin{array}{l}\text { Year } \\ \text { collected }\end{array} \\ 1 & \text { Pócs et al. } & \text { Viti Levu } & 2003 \\ 2 & \text { Pócs et al. } & \text { Viti Levu } & 2003 \\ & & & \\ 3 & \text { Pócs et al. } & \text { Viti Levu } & 2003 \\ & & & \\ 4 & \text { Fife \& Naikatini } & \text { Viti Levu } & 2003, \\ & \begin{array}{l}\text { Lumbsch et al. } \\ \text { Pócs et al. }\end{array} & 2008 \\ 5 & \text { Pócs et al. } & \text { Viti Levu } & 2008\end{array}$

$7 \quad$ Fife \& Naikatini

Viti Levu

2007

$8 \quad$ Fife \& Naikatini

Viti Levu 2007

9 Pócs et al.

Taveuni

2003

10 Pócs et al.

11 Fife \& Naikatini Lumbsch et al. Pócs et al.

12 Pócs et al.

13 Pócs et al.

Kadavu

2003

14 Pócs et al.

Vanua Levu 2006

15 Pócs et al.

Vanua Levu 2006

\section{Brief description of general area and elevation (elev.)}

Margin of Nausori Highlands, secondary submontane rainforest, 600-620 m elev.

Southern coast ("Coral Coast"), coastal forest vegetation and lowland fragmented forest, sea level to $60 \mathrm{~m}$ elev.

North-eastern coast, mosaic of dry semideciduous forest, mangrove forest, sea level to 60 m elev.

Central Highlands, Rairaimatuku Plateau, Monasavu area, Alphitonia-HomaliumMetrosideros-Scaveola-Cyathea cloud forest with emergent Dacrydium, 900-1050 m elev.

Naquaranibuluti Nature Reserve, track to $\mathrm{Mt}$ Lomalagi, mesic and dry evergreen forest with emergent Podocarpus neriifolius and Agathis vitiensis, $875 \mathrm{~m}$ elev.

Mt Korobamba, lower slopes, partly shaded volcanic rock in moderately disturbed lowland rainforest with Spathodea, Ficus, Cyathea, and Dicksonia, $75 \mathrm{~m}$ elev.

Headwaters of the Nabukavesi R., second-growth lowland rainforest dominated by Trichospermum and Endospermum, with Cyathea and Angiopteris understorey, c. $100 \mathrm{~m}$ elev.

Mt Voma, exposed vertical basalt rock face, seepage areas, $800 \mathrm{~m}$ elev.

SE coast, Wainisari Beach near estuary of Wainibau Stream, rocky (volcanic) coastal forest with tree-ferns, intercropped by Cocos nucifera). 4-10 m. elev.

Vicinity of Tavoro Waterfall, cultivated area and degraded lowland rainforest, 10-100 m elev.

NW slope of Des Voeux (Devo) peak, montane mossy forest, $900-1100$ m elev.

Central part of island, along the Namara Road, slopes of secondary lowland rainforest on lilac volcanic soil, 120-165 m elev.

Western part of island, slopes and summit of Koroniquala Hill, mesic submontane rainforest with tree-ferns, 250-370 m elev.

Coastal mangrove forest, on the outskirts of Labosa, sea level-5 m.

Waisali Dakua National Trust Forest Reserve, dominated by Agathis macrophylla, to $450 \mathrm{~m}$ elev. 


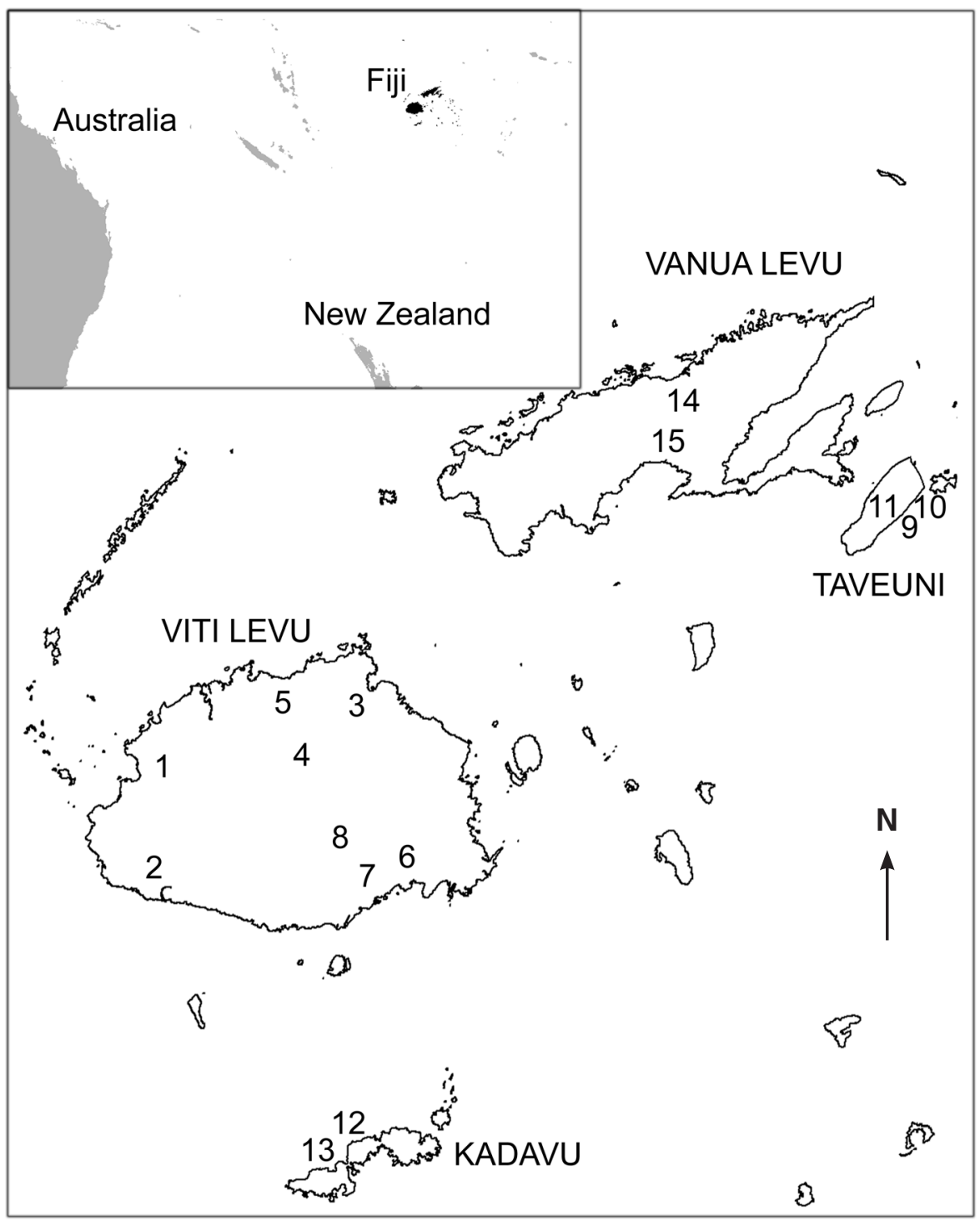

Fig. 1. An overview of major sites on the islands Viti Levu, Vanua Levu and Taveuni visited between 2003 and 2008 by bryologists and lichenologists in the current issue. See Table 1 for a brief description of general area and elevation. Inset of Oceania. 
Challenger expedition (1872-1876) that made several visits to Fiji was "apparently a keener collector than he was presser, labeller and cataloguer of plants during the voyage, a fact that probably contributed to his forced resignation at the instigation of Hooker" (Meagher 2003). One example of a report that is probably misplaced is the type of Sphagnum weberi Warnst., said to come from Samoa, but there is no locality there to fit the labelling. It seems most likely that the specimen is not from Samoa and could actually be from New Guinea (Séneca \& Söderström 2011, this issue). Another problem is the frequent confusion of islands and archipelagoes by the botanists who identified the plants, but had never been to the Pacific and were unfamiliar with the region. Common examples of this kind of confusion are the locality details 'Samoa, Ovalau', which confuses a Fijian island with the Samoan archipelago, or even worse, 'Fiji, Oahu', which confuses a Hawaiian Island with the Fijian archipelago. The latter case might be explained if 'Oahu' is actually a misprint of 'Ovalau', a Fijian Island. Another example is that Mitten (1873a, b) sometimes refers to Hawaii as the Sandwich Islands, and other times as Hawaii, suggesting that he did not know that they are the same.

\section{Prospects for the future}

It is clear that Fijian ferns, bryophytes, and lichenised fungi have been overlooked historically, compared to seed plants, birds, and other organisms in Fiji, forming a remarkable gap in the flora of Fiji. Moreover, the state of our floristic knowledge of these organisms is deficient compared to many other biodiversity hotspots and other ecologically significant areas of the globe. This is particularly alarming as Conservation International identified the islands of the South Pacific as the "epicenter of the global extinction crisis", largely because of the high proportion of extinct species and habitat loss (http://www.conservation.org/where/priority_areas/hotspots/asiapacific, accessed 16 Aug 2011). The flora of the Fijian islands has also received very little attention in comparison to the two developed countries of the South Pacific Australia and New Zealand - as well as other large islands in the region, e.g. New Caledonia. Dedicated study of cryptogams from Fiji would thus increase the regional knowledge of these elements of the flora.

The immediate future looks promising as several international and national agencies have recently identified and financially supported the critical need to investigate these organisms, e.g. Conservation International, National Geographical Exploration and Research, the New Zealand Agency for International Development and the Warwick Foundation. Funding opportunities also present a strong foundation to develop and foster capacity building with Fijian scientists, which is essential to the long-term sustainability of documenting the biodiversity of cryptogams across the islands. It seems evident from the 180 new records, and the recent discovery of species new to science, that the islands of Fiji require further botanical exploration (e.g. Pócs 2008a, b; Pócs et al. 2011, this issue; Lumbsch et al. 2010, 2011b, this issue).

Their vast morphological diversity, phylogenetic importance, and key roles in the ecosystems of the world, make bryophytes, lichens and ferns useful objects of study in many interesting and new avenues of study. Continued field programs and collecting activities focused on these organisms will have broad ramifications. Carefully designed research in Fiji has the potential to serve as a model for similar survey work in other islands of the South Pacific, help develop local scientific expertise, and greatly facilitate study of these organisms beyond taxonomy and biodiversity, such as their application 
to conservation. Development of local scientific expertise and capacity-building will be particularly important in enhancing research on these overlooked organisms. Training of, and collaboration with, scientists in Fiji will enable them to make scientifically informed assessments of different ecosystems, and contribute to training programs in applications of these organisms to conservation science. The islands of Fiji represent areas of varying geological ages and history and provide a promising venue for the study of biogeographical patterns of selected cryptogam groups. Bryophyte species composition and their distribution over time have been used in the past to determine the size and shape of forest patches necessary for the maintenance of interior forest conditions (Sillet et al. 1995) and as potential indicators of large scale changes to an ecosystem (Gignac 2001). Field programs in Fiji could also contribute to exploring the functional role of cryptogams in tropical ecosystems, their use and application as bioindicators of forest degradation, land use change, and conservation.

\section{Synopsis of current issue}

The lack of data for cryptogams in Fiji is significant and thus the papers presented in this issue of Telopea are of particular importance. The issue contains six papers on Fijian cryptogams, two focused on mosses, two on liverworts and hornworts, one devoted to ferns and another to lichenised fungi. Séneca \& Söderström on Sphagnum, provide an overview of the six taxa recorded for the Pacific Islands (two from Fiji) and there is a report on 17 interesting mosses from Fiji by Fife, including new distributional information for nine species. Pócs et al. provide a report of 48 species of liverworts new to the Fiji Islands and new island distributions for an additional 39 taxa. Söderström et al. provide a detailed and comprehensive checklist of liverworts and hornworts including 289 taxa, with annotations and notes; a vital entry point to assess the biodiversity of these organisms in all future studies. An annotated and revised checklist of 331 species of Fijian ferns and lycophytes is presented by Brownsey \& Perrie, the first updated checklist published in over three decades. Lumbsch et al. report 66 lichenised fungi species from the Fijian archipelago for the first time, including a remarkable 19 additional genera. Diagnostic features and distribution areas are given for each species. We anticipate the issue will contribute to further research as well as assisting more students in the study and enjoyment of these intriguing organisms.

Two papers on Australian bryophytes also provide an interesting perspective on the state of knowledge in a more resourced and studied country from the region. Ramsay summarises current knowledge on meiotic chromosome numbers; some 180 collections, comprising 80 species in 57 genera of Australian mosses. Renner provides valuable range extension and new records for seven taxa of Lejeuneaceae.

\section{Acknowledgments}

The financial assistance of the National Geographic Committee for Research and Exploration (Grant No. 8247-07), GBIF Seed Money Award No. 2007/41, Critical Ecosystem Partnership Fund, Warwick Foundation, the New Zealand Agency for International Development and an anonymous donor are gratefully acknowledged. The authors also gratefully acknowledge the anonymous referees who greatly improved the paper. 


\section{References}

Archer AW (2004) Additions to the lichen flora of Fiji and Vanuatu based on Graphidaceae in the Wilson FRM collection at the National Herbarium of New South Wales. Telopea 10: 771-776.

Asakawa Y (1995) Chemical constituents of Hepaticae. Pp. 1-562 in Herz W, Kirby GW, Moore RE, Steglich W \& Tann C (eds) Progress in the Chemistry of Organic Natural Products, vol. 65. (Springer: Wein).

Asakawa Y (2004) Chemosystematics of the Hepaticae. Phytochemistry 65: 623-669.

Bates JW \& Farmer AM (1992) Bryophytes and lichens in a changing environment. (Clarendon Press: Oxford).

Bartram EB (1936) Contribution to the mosses of Fiji. Bishop Museum Occasional Papers 11: $1-30$.

Bartram EB (1948) Additional Fijian mosses. Bishop Museum Occasional Papers 19: 219-231.

Bartram EB (1956) Additional Fijian mosses III. Journal of the Washington Academy of Sciences 46: 392-396.

Brackenridge WD (1854) United States Exploring Expedition, Volume XVI - Botany - Filices (By Authority of Congress, C. Sherman, Philadelphia, Pennsylvania).

Brownlie G (1977) The pteridophyte flora of Fiji. (Cramer: Vaduz).

Brownsey PJ (1987) A review of the fern genus Hypolepis (Dennstaedtiaceae) in the Malesian and Pacific regions. Blumea 32: 227-276.

Brownsey PJ \& Perrie LR (2011) A revised Checklist of Fijian ferns and lycophytes. Telopea 13: $513-562$.

Campbell EO (1971) Liverworts collected in Fiji by Smith AC \& Greenwood W. Journal of the Royal Society of New Zealand 1: 7-30.

Copeland EB (1929) Ferns of Fiji. Bernice P. Bishop Museum Bulletin 59: 1-105.

Cornelissen JHC, Lang SI, Soudzilovskaia NA \& During HJ (2007) Comparative cryptogam ecology: a review of bryophyte and lichen traits that drive biogeochemistry. Annals of Botany 99: 987-1001.

Coxson DS, McIntyre DD \& Vogel HJ (1992) Nutrient release from epiphytic bryophytes in tropical montane rain forest. Canadian Journal of Botany 69: 2122-2129.

Crandall-Stotler B \& Stotler RE (2000) Morphology and classification of the Marchantiophyta. Pp. 21-70 in Shaw AJ \& Goffinet B (eds) Bryophyte Biology. (Cambridge University Press: Cambridge).

David A (1995) The Voyage of HMS Herald to Australia and the South-west Pacific 1852-1861 under the command of Captain Henry Mangles Denham. (Miegunyah Press).

Davis SD, Heywood VH \& Hamilton AC (1995) Centres of plant diversity: a guide and strategy for their conservation. Vol. 2 Asia, Australasia, and the Pacific. (WWF and IUCN: Cambridge, UK).

Dixon HN \& Greenwood W (1930) The Mosses of Fiji. Proceedings of the Linnean Society of New South Wales 55: 261-302.

DoE (Department of the Environment) (1997) Convention on Biological Diversity 1997. National Report to the Conference of the Parties by the Republic of Fiji. (Department of the Environment, Ministry of Local Government, Housing and Environment: Suva, Fiji).

Eddy A (1988) A Handbook of Malesian Mosses. Vol. 1. Sphagnales to Dicranales. (Natural History Museum: London).

Eddy A (1990) A Handbook of Malesian Mosses. Vol. 2. Leucobryaceae to Buxbaumiaceae. (Natural History Museum Publications: London).

Eddy A (1996) A Handbook of Malesian Mosses. Vol. 3. Splachnobryaceae to Leptostomataceae. (Natural History Museum and HMSO, London).

Elix JA (2001) Additional lichen records from Oceania 7. Parmeliaceae from Fiji. Australasian Lichenology 48: 34-37.

Elix JA \& McCarthy PM (1998) Catalogue of the lichens of the smaller Pacific islands. Bibliotheca Lichenologica 70: 1-361. 
Elix JA \& McCarthy PM (2008) Checklist of Pacific Island Lichens. Australian Biological Resources Study, Canberra. Version 21 August 2008. [Accessed at http://www.anbg.gov.au/ abrs/lichenlist/PACIFIC_introduction.html]

Engel JJ \& Glenny D (2008) A Flora of the Liverworts and Hornworts of New Zealand, vol. 1, 897 p.p. (Missouri Botanical Garden Press: St. Louis).

Fife AJ \& Naikatini A (2011) Significant records of Fijian mosses. Telopea 13:495-502.

Gardner RO (1997) A concise account of Selaginella in Fiji. New Zealand Journal of Botany 35: 269-281.

Gargas A, DePriest PT, Grube M \& Tehler A (1995). Multiple origins of lichen symbioses in Fungi suggested by SSU rDNA phylogeny. Science. 268: 1492-1495.

Gibbs LS (1909) A contribution to the montane flora of Fiji (including Cryptogams), with ecological notes. Journal of the Linnean Society, Botany 39: 130-212.

Gignac LD (2001) New frontiers in bryology and lichenology: Bryophytes as indicators of climate change. The Bryologist 104: 410-420.

Godley EJ (2000) Biographical Notes (39): Garth Brownlie (1920-1986). New Zealand Botanical Society Newsletter 61 (September): 26-28.

Greenwood W (1945) Notes on some Fijian mosses. Proceedings of the Linnean Society of New South Wales 70: 213-218.

Hattori S (1985) A small collection of Frullania and Porella (Hepaticae) made on Viti Levu, Fiji Islands. Bulletin of the National Science Museum, Tokyo. Series B, Botany 11: 11-17.

Heads M (2006) Seed plants of Fiji: an ecological analysis. Biological Journal of the Linnean Society 89: 407-431.

Iwatsuki Z \& Suzuki T (1996) Fissidens in the Fiji Islands. Journal of the Hattori Botanical Laboratory 79: 139-162.

Jack JB \& Stephani F (1894) Hepaticae in insulis Vitiensibus et Samoanis a Dre Ed. Graeffe anno 1864 lectae. Botanisches Centralblatt 60: 97-109.

Kato M (1984) A taxonomic study of the athyrioid fern genus Deparia with main reference to the Pacific species. Journal of the Faculty of Science, University of Tokyo, sect. III, 13: 375-429.

Kenrick P \& Crane PR (1997) The origin and early evolution of plants on land. Nature 389: 33-39.

Keppel G (2005) Botanical studies within the PABITRA Wet-Zone Transect, Viti Levu, Fiji. Pacific Science 59: 165-174.

Kramer KU \& Zogg E (1988) Pseudophegopteris (Thelypteridaceae) in Fiji, a new record and a new species. Blumea 33: 423-426.

Krempelhuber A (1868) Exotische Flechten aus dem Herbar des k.k. botanischen Hofkabinetes in Wien. Verhandlungen der Zoologisch-Botanischen Gesellschaft in Wien. Vienna 18: 303-330.

Krempelhuber AV (1873) Beitrag zur Kenntniss der Lichenen-Flora der Südsee-Inseln. Journal des Museum Godeffroy, Geographische, ethnographische und naturwissenschaftliche Mittheilungen 1: 93-110.

Longton RE (1984) The role of bryophytes in terrestrial ecosystems. Journal of the Hattori Botanical Laboratory 55: 147-163.

Longton RE (1992) The role of bryophytes and lichens in terrestrial ecosystems. Pp. 32-76 in Bates JW \& Farmer AM Bryophytes and Lichens in a Changing Environment. (Clarendon Press: Oxford).

Lücking R, Lumbsch HT \& von Konrat M (2010) Graphis collinsiae (Ascomycota: Graphidaceae), a new lichen species from the Fiji Islands. Bryologist 113: 356-359.

Lumbsch HT, Papong K \& Naikatini A (2009) A new terricolous species of Gyalidea (Gomphillaceae, Ascomycota) from Fiji. Nova Hedwigia 88: 111-116.

Lumbsch HT, Divakar PK, Messuti MI, Mangold A \& Lücking R (2010) A survey of thelotremoid lichens (Ascomycota: Ostropales) in subantarctic regions excluding Tasmania. Lichenologist 42: 203-224. 
Lumbsch HT, Ahti T, Altermann S, Amo G, Aptroot A, Arup U, Barcenas Peña A, Bawingan PA, Benatti MN, Betancourt L, Björk CR, Boonpragob K, Brand M, Bungartz F, Caceres M, Candan M, Chaves JL, Clerc P, Common R, Coppins BJ, Crespo A, Dal Forno M, Divakar PK, Duya MV, Elix JA, Elvebakk A, Fankhauser J, Farkas E, Ferraro LI, Fischer E, Galloway DJ, Gaya E, Giralt M, Goward T, Grube M, Hafellner J, Hernández J, Herrera-Campos MA, Kalb K, Kärnefelt I, Kantvilas G, Killmann D, Kirika P, Knudsen K, Komposch H, Kondratyuk S, Lawrey JD, Mangold A, Marcelli MP, McCune B, Michlig A, Miranda Gonzalez R, Moncada B, Naikatini A, Nelsen MP, Øvstedal DO, Palice Z, Papong K, Parnmen S, Pérez-Ortega S, Printzen C, Rico VJ, Rivas Plata E, Robayo J, Rosabal D, Ruprecht U, Salazar Allen N, Sancho L, Santos de Jesus L, Santos Vieira T, Schultz M, Seaward MRD, Sérusiaux E, Schmitt I, Sipman HJM, Sohrabi M, Søchting U, Søgaard MZ, Sparrius L, Spielmann AA, Spribille T, Sutjaritturakan J, Thammathaworn A, Thell A, Thor G, Thüs H, Timdal E, Truong C, Türk R, Umaña Tenorio L, Upreti DK, van den Boom P, Vivas Rebuelta M, Wedin M, Will-Wolf S, Wirth V, Wirtz N, Yahr R, Yeshitela K, Ziemmeck F, Lücking R (2011a) One hundred new species of lichenized fungi: a signature of undiscovered global diversity. Phytotaxa 18: 1-127.

Lumbsch HT, Lücking R, Divakar PK, von Konrat M \& Naikatini A (2011b) New records of lichen-forming fungi from Fiji. Telopea 13: 375-404.

Lutzoni F, Pagel M \& Reeb V (2001) Major fungal lineages are derived from lichen symbiotic ancestors. Nature 41: 937-940.

Matsui T \& Iwatsuki Z (1993) Callicostaceae and Daltoniaceae (Hookeriales, Musci) from Fiji and Vanuatu. Hikobia 11: 281-284.

McCarthy PM \& Elix JA (2000) Additional lichen records from Oceania 4. Some pyrenolichens in Fiji. Australasian Lichenology 46: 40-42.

Meagher D (2003) Bryophyte records. Australasian Bryological Newsletter 48: 8-10.

Miadlikowska J, Kauff F, Hofstetter V, Fraker E, Grube M, Hafellner J, Reeb V, Hodkinson BP, Kukwa M, Lücking R, Hestmark G, Otalora MG, Rauhut A, Büdel B, Scheidegger C, Timdal E, Stenroos S, Brodo I, Perlmutter GB, Ertz D, Diederich P, Lendemer JC, May P, Schoch CL, Arnold AE, Gueidan C, Tripp E, Yahr R, Robertson C \& Lutzoni F (2006) New insights into classification and evolution of the Lecanoromycetes (Pezizomycotina, Ascomycota) from phylogenetic analyses of three ribosomal RNA and two protein-coding genes. Mycologia 98: 1088-1103.

Miller HA, Whittier HO \& Whittier BA (1978) Prodromus Florae Muscorum Polynesiae. Bryophtorum Biblotheca 16: 1-334.

Miller HA, Whittier HO \& Whittier BA (1983) Prodromus Florae Hepaticarum Polynesiae. Bryophytorum Bibliotheca 25: 1-423.

Mishler BD \& Churchill SP (1984) A cladistic approach to the phylogeny of the "bryophytes." Brittonia 36: 406-424.

Mitten W (1861) Musci et Hepaticae Vitiensis. Bonplandia 9: 365-367.

Mitten W (1862) Musci et Hepaticae Vitiensis. Bonplandia 10: 19.

Mitten W (1873a) Musci. Pp. 378-404 in Seemann B (ed), Flora vitiensis. (Reeve: London).

Mitten W (1873b) Jungermanniae and Marchantiae. Pp. 325-453 in Seeman B (ed.), Flora vitiensis. (Reeve: London).

Mittermeier RA, Robles GP, Hoffman M, Pilgrim J, Brooks T, Goettsch C, Mittermeier JL \& Da Fonseca GAB (2005) Hotspots revisited: Earth's biologically richest and most threatened terrestrial ecoregions (Conservation International: Chicago)

Molho DM, Bodo B, Culberson WL \& Culberson CF (1981) A chemically distinctive new Ramalina from Fiji. The Bryologist 84: 396-398.

Mueller-Dombois D \& Fosberg FR (1998) Vegetation of the Tropical Pacific Islands. Ecological Studies Vol. 132. (Springer-Verlag: New York).

Nash TH (2008) Lichen sensitivity to air pollution. Pp. 299-314. Lichen Biology (2nd edition) (Cambridge University Press: Cambridge, UK)

Page CN (1979) The diversity of ferns. An ecological perspective. Pp. 10-57 in Dyer AF (ed.) The Experimental Biology of Ferns (Academic Press: London). 
Parham JW (1972) Plants of the Fiji Islands. Revised edition. (Government Printer, Suva).

Parris BS (1994) Additions to the pteridophyte flora of Taveuni, Fiji. Fern Gazette 14: 255-258.

Pócs T (1980) The epiphytic biomass and its effect on the water balance of two rain forest types in the Uluguru Mountains (Tanzania, East Africa). Acta Botanica Academiae Scientiarum Hungaricae 26: 143-167.

Pócs T (2008a) Bryophytes from the Fiji Islands, IV. The genus Frullania Raddi (Jungermanniopsida), I., with description of F. vivipara Pócs, spec. nov. Fieldiana, Botany 47: $147-158$.

Pócs T (2008b) Bryophytes from the Fiji Islands, III. The genus Phaeolejeunea Mizut. (Lejeuneaceae), with detailed description of P. amicorum (Hürl.) Pócs, stat. nov. Fieldiana, Botany 47: 139-145.

Pócs T, Sass-Gyarmati A, Naikatini A, Braggins J, Renner, M. \& von Konrat M (2011) New liverwort (Marchantiophyta) records for the Fiji Islands. Telopea 13: 455-494.

Qiu Y-L, Li L, Wang B, Chen, Z, Dombrovska O, Lee J, Kent L, Li R, Jobson RW, Hendry TA, Taylor DW, Testa CM, \& Ambros M (2007) A non-flowering land plant phylogeny inferred from nucleotide sequences of seven chloroplast, mitochondrial and nuclear genes. International Journal of Plant Sciences 168: 691-708.

Schiffner V (1890) Lebermoose (Hepaticae), mit Zugrundelegung der von Dr. A. C. M. Gottsche ausgeführten Vorarbeiten. Pp. 1-45 in Naumann FC (ed.) Die Forschungsreise S. M. S. "Gazelle" in der Jahren 1874 bis 1877 unter Kommando des Kapitän zur See Freiherrn von Schleinitz, Vol. IV. (Berlin).

Schoch CL, Crous PW, Groenewald JZS, Boehm EWA, Burgess TI, et al. (2009) A class-wide phylogenetic assessment of Dothideomycetes. Studies in Mycology 64: 1-15.

Schultze-Motel W (1974) Die Moose der Samoa-Inseln. Willdenowia 7: 333-408.

Schuster RM \& Engel J (1985) Austral HepaticaeV(2). Temperate and subantarctic Schistochilaceae of Australasia. Journal of the Hattori Botanical Laboratory 58: 255-539.

Seemann E (1865-1873) Flora Vitiensis: a description of the plants of the Viti or Fiji islands, with an account of their history, uses, and properties. (MacMillan Company: London).

Séneca A \& Söderström L (2011) Sphagnum of the Pacific. Telopea 13: 503-511.

Shaw AJ \& Renzaglia KS (2004) Phylogeny and diversification of bryophytes. American Journal of Botany 91: 1557-1581.

Sillet SC, Gradstein SR \& Griffin D (1995) Bryophyte diversity of Ficus tree crowns from cloud forest and pasture in Costa Rica. The Bryologist 98: 251-260.

Smith AR, Pryer KM, Schuettpelz E, Korall P, Schneider H \& Wolf PG (2006) A classification for extant ferns. Taxon 55: 705-731.

So ML (2002) The Genus Porella (Porellaceae, Hepaticae) in Australasia and the South Pacific. Systematic Botany 27: 4-13.

Söderström L, Hagborg A, Pócs T, Sass-Gyarmati A, Brown E, von Konrat M \& Renner M (2011) Checklist of hornworts and liverworts of Fiji. Telopea 13: 405-454.

Soeder RW (1985) Fern constituents: including occurrence, chemotaxonomy and physiological activity. Botanical Review 51: 442- 536.

Stearn WT (1963) “Seemann's 'Flora Vitiensis' (1865-73)". Journal of the Society for the Bibliography of Natural History 4: 151-152.

Sullivant W (1854) Notices of some new species of mosses from the Pacific Islands. Proceedings of the American Academy of Arts and Sciences 3: 73-81.

Sullivant W (1859) Musci. In: United States Exploring Expedition during the years 1838, 1839, 1840, 1841, 1842 under the command of Charles Wilkes, U.S.N. 17: 1-112.

Thiers BM (1993) A monograph of Pleurozia (Hepaticae, Pleuroziaceae). The Bryologist 96: $517-554$.

von Konrat MJ, Braggins JE, Asakawa Y \& Toyota M (2006) Frullania chevalieri (Jubulaceae) in New Zealand, with a reassessment of Schusterella. The Bryologist 109: 141-156. 
von Konrat M, Renner MAM, Söderström L, Hagborg A \& Mutke J (2008) Early Land Plants Today: Liverwort species diversity and the relationship with higher taxonomy and higher plants. Fieldiana, Botany 47: 91-104.

von Konrat M, Söderström L \& Hagborg A (2010) The Early Land Plants Today project: A community-driven effort and a new partnership with Phytotaxa. Phytotaxa 9: 11-21.

Watkins AJ (1994) A biogeographic database for seed plants of Fiji, a preliminary communication. South Pacific Journal of Natural Science 14: 75-96.

Watling D \& Chape SA (1992) Environment Fiji - the National IUCN (World Conservation Union: Suva, Fiji).

Whittier HO (1975) A preliminary list of Fijian mosses. Florida Science 38: 85-106.

Manuscript received 19 January 2011, accepted 22 August 2011 